\title{
ELISA measurement of specific non-antigen- bound antibodies to $A \beta 1-42$ monomer and soluble oligomers in sera from Alzheimer's disease, mild cognitively impaired, and noncognitively impaired subjects
}

Andrea C Klaver ${ }^{1}$, Mary P Coffey², Lynnae M Smith', David A Bennett ${ }^{3,4}$, John M Finke ${ }^{5}$, Loan Dang ${ }^{6}$ and David A Loeffler ${ }^{1 *}$

\begin{abstract}
Background: The literature contains conflicting results regarding the status of serum anti-A $\beta$ antibody concentrations in Alzheimer's disease (AD). Reduced levels of these antibodies have been suggested to contribute to the development of this disorder. The conflicting results may be due to polyvalent antibodies, antibody "masking" due to A $\beta$ binding, methodological differences, and/or small sample sizes. The objectives of this pilot study were to compare serum anti-A $\beta$ antibody concentrations between $A D$, mild cognitive impairment (MCl), and elderly noncognitively impaired $(\mathrm{NCl})$ subjects while addressing these issues, and to perform power analyses to determine appropriate group sizes for future studies employing this approach.

Methods: Serum antibodies to A 1-42 monomer and soluble oligomers in AD, $\mathrm{MCl}$, and $\mathrm{NCl}$ subjects (10/group) were measured by ELISA, subtracting polyvalent antibody binding and dissociating antibody-antigen complexes. Differences in mean antibody levels were assessed for significance with repeated measures ANOVA using restricted maximum likelihood estimation, using Tukey-Kramer tests and confidence intervals for multiple comparisons. Spearman's rank correlation was used to determine associations between anti-monomer and anti-oligomer antibody concentrations. Estimated sample sizes required to detect effects of various sizes were calculated.

Results: There were no significant differences between groups for mean anti-A $\beta$ antibody levels, although these tended to be higher in AD than $\mathrm{NCl}$ specimens. Estimated group sizes of 328 and 150 for anti-A $\beta$ monomer and oligomer antibodies, respectively, would have been required for $80 \%$ power for significance at 0.05 for a $25 \%$ increase in the $\mathrm{AD}$ mean relative to the $\mathrm{NCl}$ mean. Serum antibody concentrations to $A \beta$ monomer and oligomers were strongly associated (correlations: 0.798 for undissociated sera, 0.564 for dissociated sera). Antibody-antigen dissociation significantly increased anti-A $\beta$ monomer but not anti-A $\beta$ oligomer antibody levels.

Conclusions: The findings in this pilot study are consistent with relatively similar concentrations of specific, nonantigen-bound antibodies to $A \beta 1-42$ monomer and soluble oligomers in $A D, M C l$, and $\mathrm{NCl}$ sera. The differences between groups for these antibodies would have required approximate group sizes of 328 and 150, respectively, for a high probability for statistical significance. These findings do not support the hypothesis that reduced levels of anti-A $\beta$ antibodies might contribute to AD's pathogenesis.
\end{abstract}

\footnotetext{
* Correspondence: DLoeffler@beaumont.edu

'Department of Neurology Research, William Beaumont Hospital Research Institute, Royal Oak, MI 48073, USA

Full list of author information is available at the end of the article
} 


\section{Background}

Amyloid-beta $(A \beta)$, the major plaque-associated protein in the Alzheimer's disease (AD) brain, has become the main target for AD therapy since the formulation of the "amyloid hypothesis" [1]. The significance of serum antibodies to $\mathrm{A} \beta$ in $\mathrm{AD}$ is unclear, because these antibodies have been reported to be decreased [2-7], unaltered [8-12], or increased [13-17] in this disorder. These studies are summarized in Table 1 . Some investigators have suggested that reduced levels of anti-A $\beta$ antibodies may contribute to the pathogenesis of $\mathrm{AD}[18,19]$.

In previous studies [20,21] we used enzyme-linked immunosorbent assay (ELISA) to measure antibodies to A $\beta$ 1-42 monomer and soluble oligomers in intravenous immunoglobulin (IvIg) preparations. IvIg preparations consist of pooled and purified plasma immunoglobulins (> 95\% IgG) from thousands of clinically normal individuals. These drugs are being evaluated as a possible treatment for $\mathrm{AD}$; encouraging results were obtained in two clinical trials in which IvIg was administered to AD patients [22,23] and a multi-site phase 3 trial is in progress. In our ELISA studies we found that in addition to IvIg's binding to A $\beta$-coated wells, it also bound extensively to wells coated with buffer or with an irrelevant protein, bovine serum albumin (BSA). We referred to this as nonspecific binding $[20,21]$ and concluded that it should be subtracted from IvIg's binding to $A \beta$-coated wells to accurately calculate specific anti-A $\beta$ antibody concentrations. A subsequent study [24] found this binding to be mediated by IgG's Fab fragments and therefore referred to it as "polyvalent." Among previous studies comparing serum anti-A $\beta$ levels between $\mathrm{AD}$ patients and aged normal controls, in only one study [3] was this binding subtracted from total antibody binding to $A \beta$. The conflicting results for anti-A $\beta$ serum antibodies in $\mathrm{AD}$ may be due in part to failure to account for this binding. Other reasons could include binding of anti-A $\beta$ antibodies by serum A $\beta$ (antibody "masking"), which could reduce ELISA detection of these antibodies [25], incorrect diagnosis of some study subjects (clinical diagnosis of $\mathrm{AD}$ is about $88-90 \%$ accurate $[26,27])$, differences in preparation of the $A \beta$ conformations used to detect antibody binding and/or other methodological differences, and the small sample sizes used in some studies. In previous ELISA studies comparing these antibodies in AD subjects vs. normal controls, only Moir et al. [3], Gruden et al. [14,15], and Nath et al. [13] measured antibodies to $A \beta$ soluble oligomers, which are thought to initiate AD-type pathology [28], and only Gustaw et al. [16] and Gustaw-Rothenberg et al. [17] performed antibody-antigen complex dissociation. None of the studies performed both subtraction of polyvalent binding and dissociation of antibody-antigen complexes, nor did any of the studies confirm clinical diagnoses with post-mortem examinations or perform power analyses.

Table 1 Summary of previous studies

\begin{tabular}{|c|c|c|}
\hline Study & Specimens & Results \\
\hline Hyman et al., 2001 & Plasma: $82 \mathrm{AD}, 271 \mathrm{NCl}$ & No differences between groups (ELISA) \\
\hline Weksler et al., 2002 & Serum: $19 \mathrm{AD}, 33 \mathrm{NCl}$ & Decreased AD anti-A $\beta$ levels (ELISA) \\
\hline Nath et al., 2003 & Serum: $16 \mathrm{AD}, 31 \mathrm{NCl}$ & Anti-A $\beta$ higher in $A D$ patients \\
\hline Gruden et al., 2004 & Serum: $17 \mathrm{AD}, 15 \mathrm{NCl}$ & Increased anti-Aß25-35 oligomer antibodies in AD patients (ELISA) \\
\hline Baril et al., 2004 & Serum: $36 \mathrm{AD}, 34 \mathrm{NCl}$ & No differences between groups (ELISA) \\
\hline Mruthinti et al., 2004 & Plasma: $33 \mathrm{AD}, 42 \mathrm{NCl}$ & Anti-A $\beta$ antibodies significantly (4-fold) increased in AD plasma (ELISA) \\
\hline Moir et al., 2005 & Plasma: 59 AD, $59 \mathrm{NCl}$ & $\begin{array}{l}\text { No differences for anti-A } \beta \text { monomer antibodies; decreased AD levels for } \\
\text { anti-A } \beta \text { oligomer levels (ELISA) }\end{array}$ \\
\hline $\begin{array}{l}\text { Brettschneider et al., } \\
2005\end{array}$ & Serum: $96 \mathrm{AD}, 30 \mathrm{NCl}$ & Anti-A $\beta$ levels decreased in AD (immunoprecipitation assay) \\
\hline Jianping et al., 2006 & Serum: $20 \mathrm{AD}, 20 \mathrm{NCl}$ & Decreased AD anti-A $\beta$ levels (ELISA) and avidity \\
\hline Song et al., 2007 & Serum: 153 AD, $193 \mathrm{NCl}$ & Decreased $A D$ anti-A $\beta$ levels (ELISA) \\
\hline Gruden et al., 2007 & Serum: $48 \mathrm{AD}, 28 \mathrm{NCl}$ & $\begin{array}{l}\text { Increased anti-A } \beta 25-35 \text { oligomer antibodies in AD patients (ELISA, dot } \\
\text { blot) }\end{array}$ \\
\hline Gustaw et al., 2008 & $\begin{array}{l}\text { Serum: } 23 \text { or } 35 \mathrm{AD} \text { (assays performed in two } \\
\text { laboratories), } 35 \mathrm{NCl}\end{array}$ & $\begin{array}{l}\text { Anti-A } \beta \text { levels consistently increased in AD vs. controls only after } \\
\text { dissociation }\end{array}$ \\
\hline Xu et al., 2008 & Plasma: 113 AD, $205 \mathrm{NCl}$ & No differences between groups (plaque immunoreactivity) \\
\hline Britschgi et al., 2009 & Plasma: 75 AD, $36 \mathrm{NCl}$ & No differences between groups (A $\beta$ microarrays) \\
\hline Sohn et al., 2009 & Serum: $136 \mathrm{AD}, 210 \mathrm{NCl}$ & Anti-A $\beta$ decreased in AD patients (ELISA) \\
\hline $\begin{array}{l}\text { Gustaw-Rothenberg et } \\
\text { al., } 2010\end{array}$ & Serum: $25 \mathrm{AD}<1$ year, $18 \mathrm{NCl}, 27 \mathrm{AD}>1$ year & $\begin{array}{l}\text { Anti-A } \beta \text { increased in both AD groups (ELISA) vs. NCl, before and after } \\
\text { dissociation }\end{array}$ \\
\hline
\end{tabular}

Summary of previous studies in which serum anti-A $\beta$ antibodies have been measured. (AD = Alzheimer's disease; $\mathrm{NCl}=$ aged noncognitively impaired) 
The objectives of this pilot study were therefore to compare serum antibody levels to $A \beta 1-42$ soluble conformations between AD patients, subjects with mild cognitive impairment (MCI), and aged noncognitively impaired (NCI) individuals, incorporating all of these procedures, and to perform power analyses on the resulting data to obtain estimates of appropriate group sizes for future studies using this approach. Our findings suggest that relatively similar levels of specific, non-antigen-bound antibodies to soluble $A \beta 1-42$ conformations are present in AD, MCI, and NCI sera. Large numbers of samples (estimated group sizes: 328 and 150 for anti$\mathrm{A} \beta$ monomer and oligomer antibodies, respectively) would be required for a high probability of achieving statistical significance for the between-group differences with this approach.

\section{Methods}

\section{Serum samples}

Serum samples were obtained from the Rush Alzheimer's Disease Center (Chicago, IL) from individuals whose diagnosis on the basis of post-mortem clinical review was $\mathrm{AD}, \mathrm{MCI}$, or $\mathrm{NCI}$. MCI subjects had only one impaired cognitive domain and no other apparent cause of cognitive impairment. AD patients had no other apparent cause of cognitive impairment. These individuals were participants in the Rush Memory and Aging Project, a community-based, longitudinal clinicalpathologic study of aging and AD. Details of this project were published previously [29]. The study was approved by the Institutional Review Board of Rush University Medical Center and was given exempt status by Beaumont's Human Investigation Committee. Subject summary statistics are shown in Table 2.

\section{A $\beta$ 1-42 monomer and soluble oligomer preparations}

$\mathrm{A} \beta$ monomer was prepared as described previously [20,21,30]. A $\beta 1-42$ (0.5 mg; AnaSpec, San Jose, CA) was disaggregated by resuspending in $0.25 \mathrm{ml}$ trifluoroacetic acid (TFA, Sigma-Aldrich, Inc., St. Louis, MO) followed by hexafluoro-2-propanol (HFIP, Sigma-Aldrich). It was aliquoted into eppitubes $(20 \mu \mathrm{l} /$ tube), dried overnight (16-20 hr) at room temperature in a fume hood, and stored at $-20^{\circ} \mathrm{C}$. The $\mathrm{A} \beta$ was resuspended in HPLCgrade water adjusted to $\mathrm{pH} 3.0$ with TFA $(1 \mu \mathrm{l}$ TFA per $10 \mathrm{ml} \mathrm{HPLC} \mathrm{H}_{2} \mathrm{O}$ ). $0.6 \mathrm{ml}$ TFA water was added to an $\mathrm{A} \beta$-containing eppitube, and after thorough vortexing, this was put on ice in a separate tube. The procedure was repeated twice more on the same eppitube, yielding $1.8 \mathrm{ml}$ of $\mathrm{A} \beta$ in TFA water. Tris base $(21.8 \mathrm{mg})$ was added to bring the Tris concentration to $100 \mathrm{mM}$, and $3.8 \mu \mathrm{l}$ of $12.1 \mathrm{~N} \mathrm{HCl}$ was added to adjust the $\mathrm{pH}$ to 8.8 . The preparation was centrifuged $(11,752 \times \mathrm{g}, 5 \mathrm{~min})$, passed through a $0.2 \mu \mathrm{m}$ filter, and used immediately. The protein concentration of the filtered preparation was $6 \mu \mathrm{g} / \mathrm{ml}$ with the Bio-Rad Protein Assay (Bio-Rad Laboratories, Hercules, CA).

$\mathrm{A} \beta$ oligomers were also produced as described previously [20,30]. $4.8 \mu \mathrm{l}$ of $1 \% \mathrm{NH}_{4} \mathrm{OH}$ (AnaSpec) was added to an eppitube of disaggregated $A \beta$, and after brief vortexing, the tube sat for one min. The contents of the tube were then transferred sequentially to two more $A \beta$ eppitubes, following this same procedure each time. The preparation was water bath sonicated for 4 min, then incubated for one hr at room temperature. After dilution in phosphate buffered saline (PBS; 0.01 $\mathrm{M}, \mathrm{pH} 7.4$, with $0.02 \%$ azide) to a final concentration of $58 \mu \mathrm{g} / \mathrm{ml}$, it was used immediately or stored at $4^{\circ} \mathrm{C}$ for up to one week.

\section{Western blots of $A \beta$ conformations}

Western blots of $A \beta$ monomer and soluble oligomer preparations were performed under both reducing/denaturing and native conditions as described previously [20,30] using 4-20\% Tris-HCl Ready Gels (Bio-Rad Laboratories, Hercules, CA). The molecular weight

Table 2 Subject summary statistics by group (based upon post-mortem clinical review).

\begin{tabular}{|c|c|c|c|c|c|}
\hline Diagnosis & Gender & Age at Death (yrs) & PMI (hrs:mins) & ApoE Alleles & Anti-Inflammatory Usage \\
\hline $\mathrm{NCl}$ & $\begin{array}{c}2 \text { male } \\
8 \text { female }\end{array}$ & $89.46 \pm 1.32$ & $\begin{array}{c}6: 21 \\
(3: 40,62: 24)\end{array}$ & $\begin{array}{l}\text { E2E3: } 2 \\
\text { E3E3: } 6 \\
\text { E3E4: } 1^{*}\end{array}$ & 6 yes, 4 no \\
\hline $\mathrm{MCl}$ & $\begin{array}{c}3 \text { male } \\
7 \text { female }\end{array}$ & $89.73 \pm 1.41$ & $\begin{array}{c}4: 43 \\
(2: 55,20: 30)\end{array}$ & $\begin{array}{l}\text { E2E2: } 1 \\
\text { E2E3: } 3 \\
\text { E3E3: } 3 \\
\text { E3E4: } 3\end{array}$ & 6 yes, 4 no \\
\hline$A D$ & $\begin{array}{c}8 \text { male } \\
2 \text { female }\end{array}$ & $89.55 \pm 1.39$ & $\begin{array}{c}4: 22 \\
(1: 30,13: 35)\end{array}$ & $\begin{array}{l}\text { E2E3: } 1 \\
\text { E3E3: } 5 \\
\text { E3E4: } 4\end{array}$ & 8 yes, 2 no \\
\hline
\end{tabular}

Subject ages are reported as means \pm SEM, while PMI values are shown as medians with minimum and maximum values in parentheses. Gender distribution was significantly different between groups (chi square $p=0.020$ ) with the $A D$ group having more males than the other groups. There were no statistically significant differences between groups for age, PMl, frequency of expression of the different apoE alleles, or use of anti- inflammatory medications. ApoE status was unknown for one $\mathrm{NCl}$ subject. $(\mathrm{AD}=$ Alzheimer's disease; $\mathrm{NCl}=$ aged noncognitively impaired; $\mathrm{MCl}=$ mild cognitive impairment; $\mathrm{ApoE}=$ apolipoprotein $\mathrm{E}$; $\mathrm{PMI}=$ post-mortem interval) 
standards for the native gels were from Sigma-Aldrich's Non-Denaturing Molecular Weight Kit (cat. \# MWND500). After electrophoresis, the proteins were transferred to Westran S PVDF membranes (Whatman International Ltd., Maidstone, UK). The membranes were then blocked with $10 \%$ non-fat dry milk in $0.01 \mathrm{M}$ PBS, pH 7.4 for one hr at room temperature. Membranes were incubated overnight at $4{ }^{\circ} \mathrm{C}$ with agitation in mouse monoclonal anti-A $\beta(1-16)$ 6E10 (Covance Research Laboratories, Berkeley, CA; 1:5,000 dilution). After incubation in horseradish peroxidase (HRP)- conjugated anti-mouse IgG (Vector Laboratories, Inc., Burlingame, $\mathrm{CA} ; 1: 10,000$ dilution) for $1 \mathrm{hr}$ at room temperature, membranes were developed in SuperSignal West Pico chemiluminescent substrate (Thermo Scientific, Rockford, IL). Bands were detected on CL-XPosure film (Thermo Scientific).

\section{Transmission electron microscopy (TEM)}

TEM was performed as previously described [31]. Each sample was spread on a Formvar coated grid (Electron Microscopy Sciences, Fort Washington, PA) and incubated for two hr at room temperature, then rinsed with double distilled water. Samples were then fixed with $1 \%$ glutaraldehyde in $100 \mathrm{mM}$ phosphate buffer, $\mathrm{pH} 7.4$ for $10 \mathrm{~min}$, rinsed again with water, and stained with $1 \%$ uranyl acetate for $10 \mathrm{~min}$ followed by alkaline lead citrate for five min. Images were taken with a Morgagni 268 transmission electron microscope (FEI Company, Hillsboro, OR) equipped with a Hamamatsu digital camera.

\section{ELISA measurement of serum antibodies to $A \beta 1-42$ monomer and soluble oligomers}

Antibody concentrations to the $A \beta 1-42$ monomer and soluble oligomer preparations were measured by ELISA in $\mathrm{AD}, \mathrm{MCI}$, and $\mathrm{NCI}$ serum samples. A separate ELISA plate was required for each serum sample. The plate arrangement is shown in Figure 1. Samples were randomized as to the order in which they were evaluated. A volume of $100 \mu \mathrm{l}$ was placed in each well for each step of the procedure. The $A \beta$ monomer and soluble oligomer preparations were incubated at $0.9 \mu \mathrm{g} / \mathrm{ml}$ in Tris buffer $(0.1 \mathrm{M}, \mathrm{pH} 8.8)$ overnight at $4^{\circ} \mathrm{C}$ on a 96 -well Nunc Maxisorp plate (Nalge Nunc International, Rochester, NY). As a "specificity control" the same concentration of bovine serum albumin (BSA, Sigma-Aldrich) in Tris buffer was filtered and placed in adjacent wells. After incubation overnight at $4{ }^{\circ} \mathrm{C}$, wells were washed three times with PBS with 0.1\% Tween-20 (SigmaAldrich) (hereafter, PBS-T; this wash step was repeated after all subsequent incubations). The plate was then treated with SuperBlock (SuperBlock Blocking Buffer in PBS, Thermo Scientific) as per the manufacturer's instructions, followed by addition of antibody-antigen complex dissociated and undissociated serum samples. These samples were diluted 1:100 in PBS (pH 7.2) with $0.1 \%$ Tween-20 and 1\% BSA (hereafter, PBS-T-BSA) and assayed in quadruplicate. Positive controls were dissociated and undissociated preparations of an IvIg product, Gamunex Immune Globulin Intravenous (Human), 10\% (Talecris Biotherapeutics, Inc., Research Triangle Park, NC), diluted 1:1,000. A normal control serum sample from an individual not participating in the Rush Memory and Aging Project was included on all plates to allow data to be normalized between plates. Dissociation of serum antibody-antigen complexes with $\mathrm{pH} 3.5$ dissociation buffer was performed as previously described [20] using the procedure described by Li et al. [25] with slight modifications. To produce the standard curve, four-fold dilutions of mouse monoclonal $6 \mathrm{E} 10$ anti-A $\beta$ antibody $(1: 4,000[250 \mathrm{ng} / \mathrm{ml}], 1: 16,000[62.5 \mathrm{ng} / \mathrm{ml}]$, $1: 64,000[15.6 \mathrm{ng} / \mathrm{ml}]$, and $1: 256,000[3.9 \mathrm{ng} / \mathrm{ml}])$ in PBS-T-BSA were placed in wells previously coated with $A \beta$ monomer, $A \beta$ oligomers, or BSA. Blank wells received PBS-T-BSA at this step. Secondary antisera were biotinylated goat anti-mouse IgG (Vector Laboratories, Inc., Burlingame, CA; 1:1,000 dilution) for the wells previously receiving mouse $6 \mathrm{E} 10$ antibody and biotinylated goat anti-human IgG $(\mathrm{H}+\mathrm{L}$ ) (Jackson ImmunoResearch Laboratories, West Grove, PA; 1:1,000 dilution) for wells previously incubated with serum samples. After incubation with streptavidin-alkaline phosphatase (Zymed Laboratories, Invitrogen, Carlsbad, CA; 1:1,000 in PBS-T), para-nitrophenol phosphate (SigmaAldrich) was added (5 $\mathrm{mg}$ in $40 \mathrm{ml}$ of $1 \mathrm{M}$ diethanolamine buffer, $\mathrm{pH}$ 9.8). The plate was read at $405 \mathrm{~nm}$ with a Vmax kinetic microplate reader (Molecular Devices Corp., Sunnyvale, CA) until the standard curve OD reached 1.0. Softmax Pro software version 3.0 (Molecular Devices) was used to generate the best-fit plot of the standard curve, using the log-logit option.

\section{Calculation of serum antibody concentrations to $A \beta 1-42$ monomer and soluble oligomers}

To calculate specific anti-A $\beta$ antibody concentrations, the mean antibody concentration measured when each serum sample was incubated on BSA-coated wells was subtracted from the antibody concentrations measured on wells coated with the soluble $A \beta$ conformations. Densitometric analysis of western blots indicated that approximately $30 \%$ of the total band intensity in the $A \beta$ oligomer preparation was due to the $A \beta$ monomer band [20]. Therefore, after calculating the mean anti-monomer antibody concentration of each sample, $30 \%$ of this was subtracted from its antibodies to the oligomer preparation to determine its anti-oligomer antibody concentration. The antibody levels measured in each 


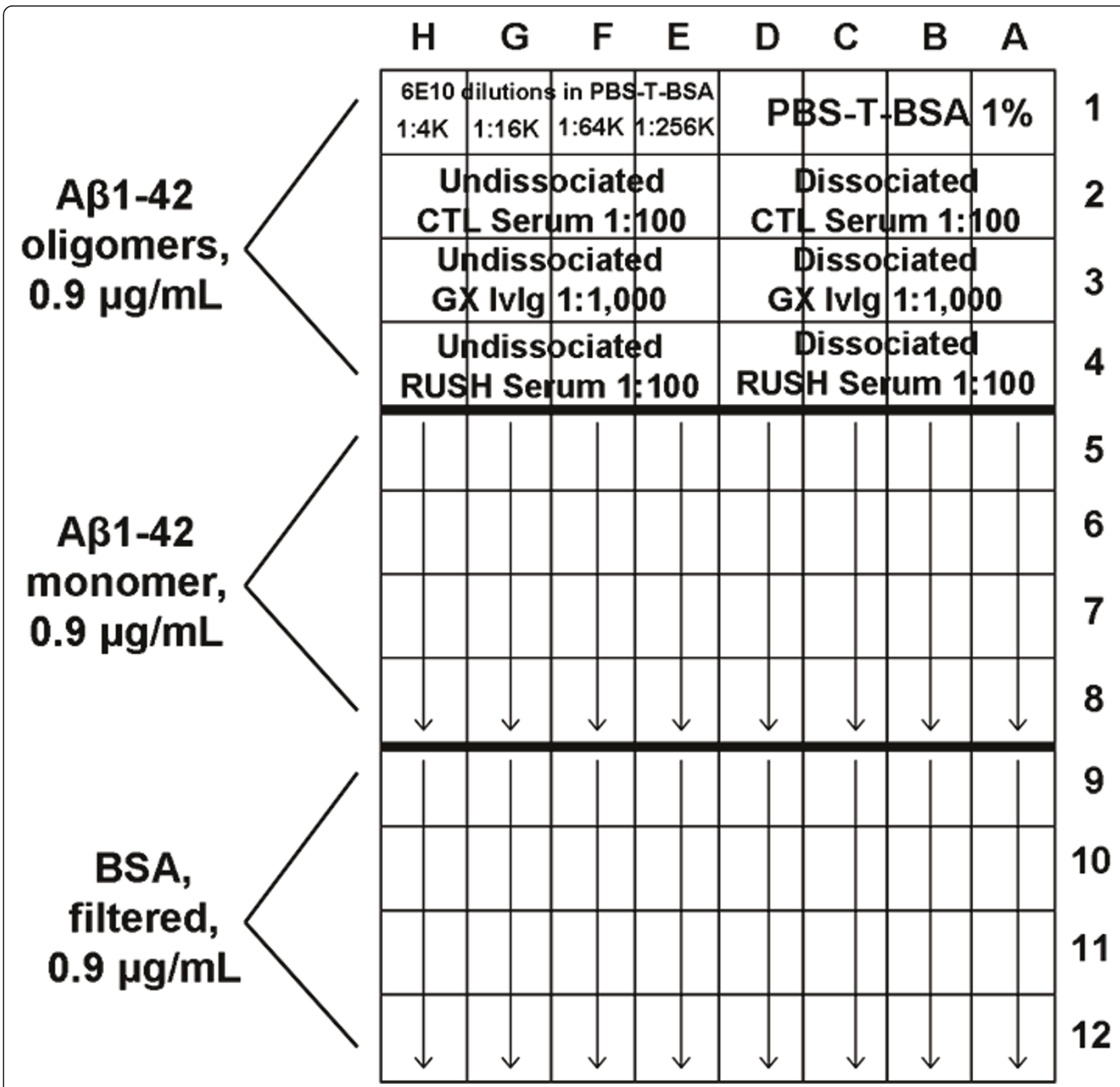

Figure 1 ELISA plate configuration used to measure specific antibodies to $\mathbf{A} \boldsymbol{\beta} 1-\mathbf{4 2}$ monomer and soluble oligomers. Antibodies to $A \beta 1-$ 42 (both monomer and soluble oligomers) were measured on a separate ELISA plate for each serum sample. The plate layout for each sample is shown. The mean antibody concentration measured when each serum sample was incubated on BSA-coated wells, representing polyvalent antibody binding, was subtracted from the antibody concentrations measured on wells coated with the soluble A $\beta$ conformations. After calculating the mean anti-monomer antibody concentration of each sample, 30\% of this was subtracted from its antibodies to the oligomer preparation to determine its anti- oligomer antibody concentration. An Ivlg sample (Gamunex) was included on all plates as a positive control. (CTL serum = normal control serum sample included on all plates to allow normalization of data between plates; Rush serum = experimental serum sample whose anti-A $\beta$ antibody concentrations were being measured; GX = Gamunex Immune Globulin Intravenous (Human), 10\%,

Talecris Biotherapeutics, Inc., Research Triangle Park, NC).

experiment were normalized for interassay variation by multiplying them by the overall mean concentration (from all 30 experiments) of anti-A $\beta$ oligomer antibodies in antibody-antigen-dissociated serum from the normal control sample, then dividing by the observed concentration of the anti-A $\beta$ oligomer antibody in this control sample in the experiment. This normalization procedure was based on anti- $\mathrm{A} \beta$ oligomer levels in dissociated sera, rather than the other anti-A $\beta$ measurements, because the most consistent findings across 
experiments were detected for dissociated anti-A $\beta$ oligomer antibody measurements.

\section{Statistical Methods}

Spearman's correlation coefficient was used to assess the association between antibody concentrations to $A \beta$ monomer and oligomeric $A \beta$ using pooled data from all groups and also within each group. Differences in mean antibody levels between groups and between sample preparation methods (either dissociated or undissociated) were assessed with repeated measures ANOVA using restricted maximum likelihood estimation with an appropriate variance structure. Main effects models were used when there was no evidence of interaction. Tukey-Kramer p-values and confidence intervals were used for multiple comparisons as appropriate. The significance of differences between groups was evaluated using one-way ANOVA (for subject age), the KruskalWallis test (for post-mortem intervals [PMI]), and exact versions of Pearson's chi-square tests (for gender, apolipoprotein $E$ [apoE] status, and use of anti-inflammatory medications). P-values $\leq 0.05$ were considered statistically significant. All p-values were two-tailed. Statistical analyses were performed using The SAS System for Windows version 9.2 .

\section{Power and sample size analyses}

All calculations were based on a significance level of 0.05 , with $80 \%$ power to detect specified differences using the $\mathrm{F}$ test for the group effect from repeated measures ANOVA. The standard deviation of concentration and the mean concentration of anti- $\mathrm{A} \beta$ antibodies in NCI sera (averaged between dissociated and undissociated samples) were estimated from the data. The power analysis calculations specified that the mean anti$\mathrm{A} \beta$ antibody concentration in AD subjects would be increased by a given percentage $(20 \%, 25 \%, 30 \%, 40 \%$, or $50 \%)$ from the antibody concentration in the NCI group. The calculations used NCPASS 2005 software with equal group sample sizes.

\section{Results}

\section{Western blots of $A \beta$ conformations}

Western blots of the $A \beta$ conformations, performed on gels run under both reducing/denaturing and native conditions, were published previously [30]. The A $\beta$ monomer preparation produced a single band in both blots. The blot of the reducing/denaturing gel of the oligomer preparation contained bands corresponding to A $\beta$ monomer, dimer, tetramer, pentamer, and higherorder oligomers. Western blots of the this preparation run on a native gel produced a protein smear in which individual bands were difficult to visualize.

\section{TEM imaging}

Spherical structures were present in both the $A \beta$ monomer and $A \beta$ oligomer preparations. The diameter of the spherical structures in the oligomer preparation ranged from 50 to $100 \mathrm{~nm}$ while the diameter of the largest spherical structure in the monomer preparation was approximately $20 \mathrm{~nm}$. TEM images are shown in Figure 2.

\section{Serum anti-A $\beta$ monomer antibodies}

There were no significant differences for serum antibody concentrations to the $A \beta$ monomer preparation between the three groups ( $\mathrm{p}=0.73$ for combined data from undissociated and dissociated serum samples), although the mean concentrations of these antibodies tended to be increased in AD vs. NCI sera (by $20 \%$ in undissociated samples and 29\% in dissociated samples). 95\% Tukey confidence intervals for differences in the mean antibody levels indicated that the possibility of large differences between these groups could not be excluded: MCI - NCI: (-0.280, 0.431); AD - NCI: (-0.243, 0.468); $A D$ - MCI: $(-0.318,0.392)$. Anti- $A \beta$ monomer antibody levels were significantly increased after antibody-antigen complex dissociation (pooled data from all subjects: $\mathrm{p}=$ 0.0011; $95 \%$ confidence interval for dissociated - undissociated: $[0.073,0.258])$, but none of the within-group differences were statistically significant after Tukey-Kramer adjustment of p-values. Data are shown in Figure 3.

\section{Serum anti-A $\beta$ oligomer antibodies}

Results were generally similar to those for anti-A $\beta$ monomer antibodies. There were no significant differences between the levels of anti- $A \beta$ oligomer antibodies beween $\mathrm{AD}, \mathrm{MCI}$, and $\mathrm{NCI}$ serum samples $(\mathrm{p}=0.58$ for pooled data), although the mean levels again tended to be increased in AD vs. NCI sera $(30 \%$ increase in

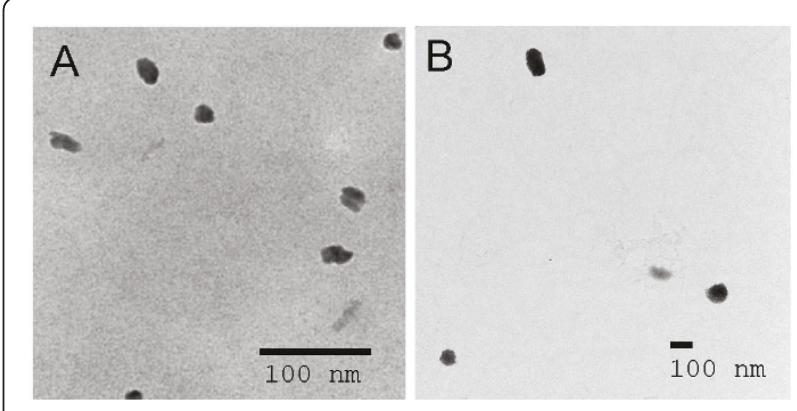

Figure 2 Transmission electron microscope (TEM) results Typical TEM images are shown in Figures $2 \mathrm{~A}$ and $2 \mathrm{~B}$ for the $\mathrm{A} \beta \mathrm{B} 1-42$ monomer and oligomer preparations, respectively. The diameters of the spherical structures seen in the $A \beta$ monomer and oligomer preparations were approximately $20 \mathrm{~nm}$ and $50-100 \mathrm{~nm}$,

respectively. 


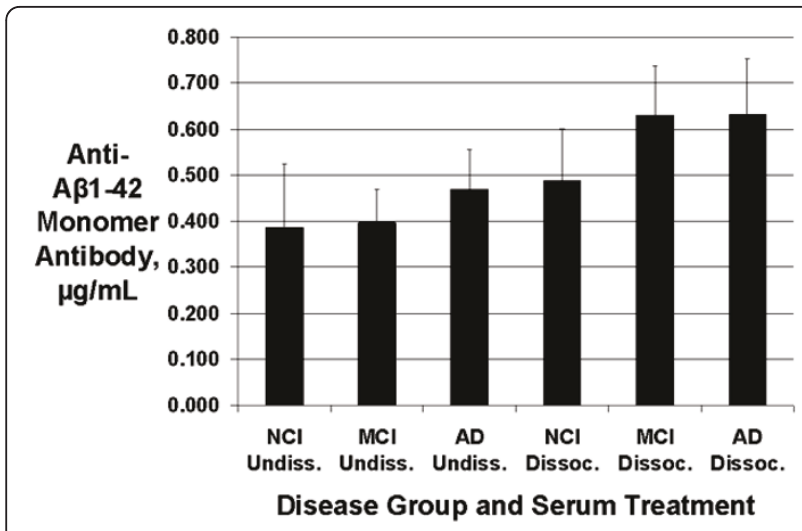

Figure 3 Serum anti-A $\boldsymbol{\beta} 1-42$ monomer antibody concentrations. No statistically significant differences were present between group means. For pooled data from all subjects, the antibody levels were significantly increased after antibody- antigen complex dissociation ( $p=0.0011$ ), but none of the within-group differences were significant after Tukey-Kramer adjustment of $p$ values. Data shown are means \pm SEM. (AD = Alzheimer's disease; $\mathrm{NCl}=$ aged noncognitively impaired; $\mathrm{MCl}=$ mild cognitive impairment; Undissoc. $=$ undissociated; Dissoc. $=$ dissociated).

undissociated sera, $13 \%$ increase in dissociated sera), and 95\% Tukey confidence intervals for the differences in mean antibody levels indicated that the possibility of large differences between the groups could not be excluded: MCI - NCI: $(-0.161,0.301)$; AD - NCI: $(-0.137,0.325)$; and AD - MCI: $(-0.207,0.255)$. In contrast to the anti-monomer antibodies, antibody- antigen dissociation did not increase mean anti-A $\beta$ oligomer antibody levels $(\mathrm{p}=0.65 ; 95 \%$ confidence interval for dissociated - undissociated $=(-0.121,0.072)$. Data are shown in Figure 4.

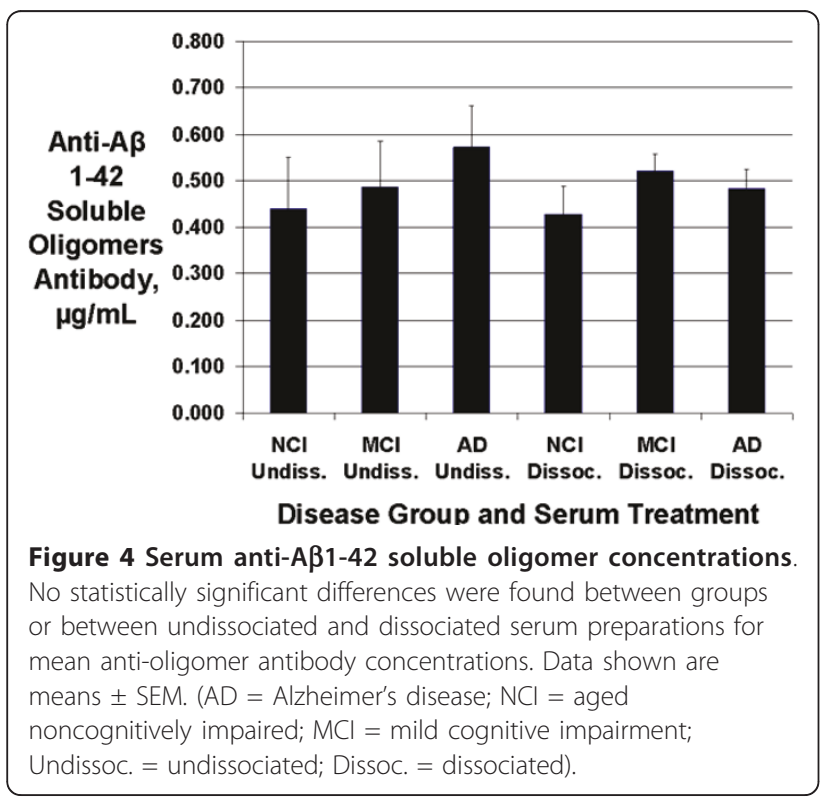

\section{Power analyses}

When the population means for serum anti-A $\beta$ monomer antibody concentrations for $\mathrm{NCI}, \mathrm{MCI}$, and $\mathrm{AD}$ subjects were modeled as $0.440 \mu \mathrm{g} / \mathrm{ml}, 0.495 \mu \mathrm{g} / \mathrm{ml}$, and $0.550 \mu \mathrm{g} / \mathrm{ml}$, specifying a $25 \%$ increase in anti- $\mathrm{A} \beta$ monomer antibody levels for AD vs. NCI subjects similar to the findings in the present study, power analysis indicated that 328 samples per group would have been required for $80 \%$ probability of statistically significant results at the 0.05 level. For anti- $\mathrm{A} \beta$ oligomer antibodies, when the population means for $\mathrm{NCI}, \mathrm{MCI}$, and $\mathrm{AD}$ were modeled as $0.433 \mu \mathrm{g} / \mathrm{ml}, 0.487 \mu \mathrm{g} / \mathrm{ml}$, and 0.541 $\mu \mathrm{g} / \mathrm{ml}$, resulting in a $25 \%$ increase in these antibodies between $\mathrm{AD}$ and NCI subjects, 150 samples per group would have been required for $80 \%$ probability of significance at the 0.05 level. Tables 3 and 4 indicate the approximate numbers of samples per group that would have been required for $80 \%$ probability to achieve significance at the 0.05 level for specified increases in $\mathrm{AD}$ vs. $\mathrm{NCI}$ antibodies to $\mathrm{A} \beta$ monomer and oligomers, respectively, between $20 \%$ and $50 \%$.

\section{Associations between anti-A $\beta$ monomer and oligomer antibody concentrations}

Antibody levels to $A \beta$ monomer and soluble $A \beta$ oligomers were strongly associated. For pooled data from all subjects, Spearman rank correlations were 0.798 for undissociated serum preparations and 0.564 for dissociated preparations. When evaluated for each group, these associations remained positive (data not shown).

\section{Evaluation of significance for differences between groups for subject variables}

There were no significant differences between groups for subject age, apoE status, PMI, or use of anti-inflammatory medications. The gender differences between the groups were statistically significant $(\mathrm{p}=0.02)$ because the majority of the AD group was male (8 males and 2 females) while the other two groups were predominantly females (NCI, 2 males and 8 females; MCI, 3 males and 7 females).

\section{Discussion}

This study used ELISA, with subtraction of polyvalent antibody binding and dissociation of antibody-antigen complexes, to compare the concentrations of serum antibodies to soluble $A \beta 1-42$ conformations between $\mathrm{AD}, \mathrm{MCI}$, and NCI subjects who were grouped on the basis of post-mortem clinical review. The betweengroup differences for serum anti-A $\beta$ levels were not statistically significant. Although the mean levels of these antibodies tended to be increased in AD vs. NCI specimens, large group sizes (estimated at 328 for anti-A $\beta$ monomer antibodies and 150 for anti-A $\beta$ oligomer 
Table 3 Power analysis for anti-Aß1-42 monomer antibody levels

\begin{tabular}{cccc}
\hline Specified \% Difference Between Means & $\mathbf{N C l}(\boldsymbol{\mu g} / \mathbf{m L})$ & AD $(\boldsymbol{\mu g} / \mathbf{m L})$ & \# Samples Required Per Group (80\% power, p < 0.05) \\
\hline $20 \%$ & 0.440 & 0.528 & 512 \\
\hline $25 \%$ & 0.440 & 0.550 & 328 \\
\hline $30 \%$ & 0.440 & 0.572 & 228 \\
\hline $40 \%$ & 0.440 & 0.616 & 129 \\
\hline $50 \%$ & 0.440 & 0.660 & 83 \\
\hline
\end{tabular}

The mean concentrations for anti- $\mathrm{A} \beta$ monomer antibodies in $\mathrm{NCl}$ specimens were determined for pooled data from undissociated and dissociated serum samples. The mean anti-A $\beta$ antibody level in AD subjects was specified to be increased by a given percentage (20-50\%) from this $\mathrm{NCl}$ antibody concentration, and for each percentage the number of samples per group required to achieve $80 \%$ statistical power at a significance level of 0.05 was calculated. Approximately 328 samples per group would have been required to detect statistical significance for the observed differences of $25.7 \%$ in this study between $\mathrm{NCl}$ and $\mathrm{AD}$ means. ( $\mathrm{AD}=$ Alzheimer's disease; $\mathrm{NCl}=$ aged noncognitively impaired)

antibodies) would have been required for a high likelihood that differences of this magnitude would be statistically significant. These sample sizes are considered to be approximate values because they are based on variability estimates from small numbers of samples. Previous studies have suggested that anti- $A \beta$ antibodies may play a protective role in $A D$, by preventing $A \beta$ 's neurotoxicity [32,33], inhibiting development of $A \beta$ soluble oligomers [21], increasing phagocytic clearance of fibrillar $A \beta$ [34], preventing $A \beta$ fibril development [35], and degrading preformed $A \beta$ fibrils [34]. Using procedures to measure specific, non-antigen-bound anti- $\mathrm{A} \beta$ antibodies, no evidence was found in the present study for altered levels of these antibodies in AD patients. Because the secondary antibody used to detect anti- $\mathrm{A} \beta$ antibodies in the serum samples, biotinylated goat anti-human IgG $(\mathrm{H}$ $+\mathrm{L}$ ), was not IgG-specific, the measurements in the present study represent total serum anti- $\mathrm{A} \beta$ antibodies rather than IgG. Our results do not support the hypothesis that decreased concentrations of serum anti-A $\beta$ antibodies may contribute to the pathogenesis of AD.

Some studies have suggested that human anti-A $\beta$ antibodies may recognize conformational epitopes on aggregated forms of $A \beta$, while not recognizing linear epitopes on monomeric $A \beta[12,33,36,37]$. However, our IvIg study [20] and the study of Moir et al. with AD and control plasma [3] suggested that these antibodies do include those to $A \beta$ monomer as well as to $A \beta$ oligomers. In the present study, specific antibodies were found in $\mathrm{AD}, \mathrm{MCI}$, and $\mathrm{NCI}$ sera to both $\mathrm{A} \beta$ monomer and oligomer preparations. In an earlier study [30] we evaluated our monomer preparation by western blot after electrophoresis on native gels, immediately after preparation and after storage at $4^{\circ} \mathrm{C}$ for more than two months. Only one band was seen in each blot, suggesting little, if any, oligomer contamination. The TEM images in the present study also showed clear differences between the $10 \mathrm{~nm}$ structures seen in the monomer preparation and the $50-100 \mathrm{~nm}$ structures observed in the oligomer preparation. These findings suggest that the antibodies measured in the present study to the $A \beta$ monomer preparation were directed to monomer rather than to $A \beta$ oligomers. However, because $A \beta$ monomer may exist in equilibrium with low-order $A \beta$ oligomers [38], the possibility is not ruled out that some of the antibody binding to the $A \beta$ monomer preparation could have been to $A \beta$ oligomers whose concentrations were below the level of detection of western blot.

A further difficulty with regard to differentiating between antibodies to $A \beta$ monomer and oligomers is that anti-monomer antibodies could also recognize $A \beta$ oligomers. The strong association between anti-monomer and anti-oligomer antibody levels in the serum samples in this study raised the issue of whether the two antibody measures may essentially be the same. Depleting the samples of anti-monomer antibodies would not necessarily resolve this issue because this might also remove some anti-oligomer reactivity, if some of the anti- $\mathrm{A} \beta$ antibodies bind to both monomers

Table 4 Power analysis for anti-Aß1-42 oligomer antibody levels

\begin{tabular}{cccc}
\hline Specified \% Difference Between Means & $\mathbf{N C l}(\boldsymbol{\mu g} / \mathbf{m L})$ & $\mathbf{A D}(\boldsymbol{\mu g} / \mathbf{m L})$ & \# Samples Required Per Group (80\% power, $\mathbf{p}<0.05)$ \\
\hline $20 \%$ & 0.433 & 0.520 & 233 \\
\hline $25 \%$ & 0.433 & 0.541 & 150 \\
\hline $30 \%$ & 0.433 & 0.563 & 59 \\
\hline $40 \%$ & 0.433 & 0.606 & 39 \\
\hline $50 \%$ & 0.433 & 0.650 & 394 \\
\hline
\end{tabular}

Approximately 150 samples per group would have been required to detect statistical significance for the observed differences of $21.8 \%$ in this study between $\mathrm{NCl}$ and $\mathrm{AD}$ means. ( $\mathrm{AD}=$ Alzheimer's disease; $\mathrm{NCl}=$ aged noncognitively impaired) 
and oligomers. If, in fact, most of the anti-monomer antibodies also recognize oligomers, then after subtracting the $\sim 30 \%$ of antibody reactivity to the oligomer preparation which is likely to be due to binding to monomers, little or no reactivity should remain. However, substantial reactivity was still detected. This suggests that at least some of the reactivity was likely to be oligomer-specific.

Previous studies reported that antibody-antigen complex dissociation may allow detection of increased levels of serum anti-A $\beta$ antibodies $[16,17,39]$. The $A \beta$ conformation to which antibodies were measured in those studies was not stated. In the present study, dissociation increased the measured concentrations of antibodies to $A \beta$ monomer but not to $A \beta$ oligomers. The dissociation procedure used $\mathrm{pH} 3.5$ dissociation buffer to separate antibody-antigen complexes, followed by passage through a $30 \mathrm{kDa}$ molecular weight cutoff filter to remove unbound $A \beta$. Unlike antibodyantigen dissociation with lower $\mathrm{pH}(2.5)$, dissociation at $\mathrm{pH} 3.5$ should not produce artifactual increases in anti-A $\beta$ antibodies or inactivate authentic antibody binding [25]. This procedure should allow removal of $\mathrm{A} \beta$ monomer (molecular weight $4.5 \mathrm{kDa}$ ) and $\mathrm{A} \beta$ oligomers no larger than hexamers $(27 \mathrm{kDa})$, while larger oligomers should be retained. A possible explanation for the lack of an increase in detectable anti- $\mathrm{A} \beta$ oligomer antibodies after dissociation is that complexes between anti- $A \beta$ antibodies and larger $A \beta$ aggregates may have re-formed after dissociation, although whether $A \beta$ oligomers are present in serum is unclear. Detection of plasma $A \beta$ oligomers by ELISA was reported by Xia et al. [40], but heterophilic antibodies may have resulted in a false positive signal in that study by crosslinking capture and reporter antibodies, as noted by Sehlin et al. [41]. We found similar false positive results (revealed as such when samples were diluted 1:1 with ELISA Diluent from Mabtech, Inc. [Mariemont, $\mathrm{OH}]$, stated by the manufacturer to prevent heterophilic antibody-related false positives) when we attempted to measure total $A \beta 1-42$ in plasma samples from the subjects in this study (data not shown).

Surprisingly, the actual concentrations of specific anti$\mathrm{A} \beta$ antibodies in serum and plasma are unclear. These antibodies have been reported as OD units [5,13,16,24], titers $[2,6,9,10,15]$, and as relative or arbitrary units $[3,4,14]$. An exception is the study by Storace et al. [39] which reported anti-A $\beta$ antibody levels from dissociated plasma samples from MCI patients and normal controls as both concentrations and OD values. The levels reported in that study ranged from 8.0 to $9.5 \mu \mathrm{g} / \mathrm{ml}$, higher than the range of $0.4-0.6 \mu \mathrm{g} / \mathrm{ml}$ in the present study. The reasons for these differences are unclear. One possibility for this discrepancy is that the concentrations for anti-A $\beta$ antibody concentrations in our study were calculated on the basis of a standard curve using mouse anti-A $\beta$ antibody, whereas Storace et al. used a purified human IgG reference standard. In addition, Storace et al. did not subtract polyvalent antibody binding.

\section{Conclusions}

We report that when specific antibodies to $A \beta 1-42$ monomer and soluble oligomers were measured by ELISA in serum specimens from subjects with postmortem clinical review diagnoses of $\mathrm{AD}, \mathrm{MCI}$, or $\mathrm{NCI}$, no significant differences in these antibody levels were found between groups even after dissociation of antibody-antigen complexes to allow measurement of "free" (non-antigen-bound) antibodies. Further, power analyses on the data indicated that large group sizes (estimated at 328 and 150 for measurements of anti-A $\beta$ monomer and oligomer antibodies, respectively) would have been necessary to achieve a high probability for the betweengroup differences in these antibody concentrations to achieve statistical significance. These results do not support the hypothesis that decreased levels of these antibodies may contribute to AD pathogenesis.

\section{List of abbreviations used}

AD: Alzheimer's disease; ApoE: apolipoprotein E; BSA: bovine serum albumin; CTL: control; dissoc: dissociated; ELISA: enzyme-linked immunosorbent assay; Ivlg: intravenous immunoglobulin; MCl: mild cognitive impairment; $\mathrm{NCl}$ : noncognitively impaired; PBS: phosphate-buffered saline; PMI: post-mortem interval; undissoc: undissociated.

\section{Acknowledgements}

We thank the participants in the Rush Memory and Aging Project and their families, as well as the staff of the Rush Alzheimer's Disease Center. This study was supported by an Oakland University-Beaumont Multidisciplinary Grant Award, donations from the Erb family and the East Detroit Auxiliary of the Fraternal Order of Eagles, and grant R01AG17917 from the National Institute on Aging (to DAB).

\section{Author details}

'Department of Neurology Research, William Beaumont Hospital Research Institute, Royal Oak, MI 48073, USA. ${ }^{2}$ Department of Biostatistics, William Beaumont Hospital Research Institute, Royal Oak, Ml 48073, USA. ${ }^{3}$ Rush Alzheimer's Disease Center, Rush University Medical Center, Chicago, IL 60612, USA. ${ }^{4}$ Department of Neurological Sciences, Rush University Medical Center, Chicago, IL 60612, USA. ${ }^{5}$ Department of Chemistry, Oakland University, 2200 Squirrel Road, Rochester, MI 48309, USA. ${ }^{6}$ Eye Research Institute, Oakland University, 2200 Squirrel Road, Rochester, Ml 48309, USA.

\section{Authors' contributions}

ACK and LMS performed the experimental procedures, collected the data, and assisted in manuscript preparation. MPC performed the data analyses and assisted with manuscript preparation. DAB provided the serum samples and assisted with manuscript preparation. JMF provided guidance with $A \beta$ monomer and oligomer preparation and assisted with manuscript preparation. LD performed the transmission electron microscope studies. DAL directed the research and wrote the manuscript. All authors read and approved the final manuscript.

\section{Competing interests}

The authors declare that they have no competing interests. 
Received: 16 May 2011 Accepted: 9 August 2011

Published: 9 August 2011

\section{References}

1. Hardy J, Allsop D: Amyloid deposition as the central event in the aetiology of Alzheimer's disease. Trends Pharmacol Sci 1991, 12:383-388.

2. Weksler ME, Relkin N, Turkenich R, LaRusse S, Zhou L, Szabo P: Patients with Alzheimer disease have lower levels of serum anti-amyloid peptide antibodies than healthy elderly individuals. Exp Gerontol 2002, 37:943-948.

3. Moir RD, Tseitlin KA, Soscia S, Hyman BT, Irizarry MC, Tanzi RE: Autoantibodies to redox-modified oligomeric Abeta are attenuated in the plasma of Alzheimer's disease patients. J Biol Chem 2005, 280:17458-17463.

4. Brettschneider S, Morgenthaler NG, Teipel SJ, Fischer-Schulz C, Bürger K Dodel R, Du Y, Möller HJ, Bergmann A, Hampel H: Decreased serum amyloid beta(1-42) autoantibody levels in Alzheimer's disease, determined by a newly developed immuno-precipitation assay with radiolabeled amyloid beta(1-42) peptide. Biol Psychiatry 2005, 57:813-816.

5. Jianping $L$, Zhibing $Y$, Wei $Q$, Zhikai $C$, Jie $X$, Jinbiao L: Low avidity and level of serum anti-Abeta antibodies in Alzheimer disease. Alzheimer Dis Assoc Disord 2006, 20:127-132.

6. Song MS, Mook-Jung I, Lee HJ, Min JY, Park MH: Serum anti-amyloid-beta antibodies and Alzheimer's disease in elderly Korean patients. J Int Med Res 2007, 35:301-306.

7. Sohn JH, So JO, Hong HJ, Kim JW, Na DR, Kim M, Kim H, Nam E, Ha HJ, Kim YH, Mook-Jung I: Identification of autoantibody against beta-amyloid peptide in the serum of elderly. Front Biosci 2009, 14:3879-3883.

8. Hyman BT, Smith C, Buldyrev I, Whelan C, Brown H, Tang MX, Mayeux R: Autoantibodies to amyloid-beta and Alzheimer's disease. Ann Neurol 2001, 49:808-810.

9. Baril L, Nicolas L, Croisile B, Crozier P, Hessler C, Sassolas A, McCormick JB, Trannoy E: Immune response to Abeta-peptides in peripheral blood from patients with Alzheimer's disease and control subjects. Neurosci Lett 2004, 355:226-230

10. Mruthinti S, Buccafusco J, Hill WD, Waller JL, Jackson TW, Zamrini EY, Schade RF: Autoimmunity in Alzheimer's disease: increased levels of circulating lgGs binding Abeta and RAGE peptides. Neurobiol Aging 2004, 25:1023-1032.

11. Xu W, Kawarabayashi T, Matsubara E, Deguchi K, Murakami T, Harigaya Y, Ikeda M, Amari M, Kuwano R, Abe K, Shoji M: Plasma antibodies to Abeta40 and Abeta42 in patients with Alzheimer's disease and normal controls. Brain Res 2008, 1219:169-179.

12. Britschgi M, Olin CE, Johns HT, Takeda-Uchimura Y, LeMieux MC, Rufibach $K_{\text {, }}$ Rajadas J, Zhang H, Tomooka B, Robinson WH, Clark CM, Fagan AM, Galasko DR, Holtzman DM, Jutel M, Kaye JA, Lemere CA, Leszek J, Li G, Peskind ER, Quinn JF, Yesavage JA, Ghiso JA, Wyss-Coray T: Neuroprotective natural antibodies to assemblies of amyloidogenic peptides decrease with normal aging and advancing Alzheimer's disease. Proc Natl Acad Sci USA 2009, 106:12145-12150.

13. Nath A, Hall E, Tuzova M, Dobbs M, Jons M, Anderson C, Woodward J, Guo Z, Fu W, Kryscio R, Wekstein D, Smith C, Markesbery WR, Mattson MP: Autoantibodies to amyloid beta-peptide (Abeta) are increased in Alzheimer's disease patients and Abeta antibodies can enhance Abeta neurotoxicity: implications for disease pathogenesis and vaccine development. Neuromolecular Med 2003, 3:29-39.

14. Gruden MA, Davudova TB, Malisauskas M, Zamotin W, Sewell RD, Voskresenskaya NI, Kostanyan IA, Sherstnev W, Morozova-Roche LA: Autoimmune responses to amyloid structures of Abeta(25-35) peptide and human lysozyme in the serum of patients with progressive Alzheimer's disease. Dement Geriatr Cogn Disord 2004, 18:165-171.

15. Gruden MA, Davidova TB, Malisauskas M, Sewell RD, Voskresenskaya NI, Wilhelm K, Elistratova El, Sherstnev W, Morozova-Roche LA: Differential neuroimmune markers to the onset of Alzheimer's disease neurodegeneration and dementia: autoantibodies to Abeta(25-35) oligomers, S100b and neurotransmitters. J Neuroimmunol 2007, 186:181-192.

16. Gustaw KA, Garrett MR, Lee HG, Castellani RJ, Zagorski MG, Prakasam A, Siedlak SL, Zhu X, Perry G, Petersen RB, Friedland RP, Smith MA: Antigenantibody dissociation in Alzheimer disease: a novel approach to diagnosis. J Neurochem 2008, 106:1350-1356.
17. Gustaw-Rothenberg KA, Siedlak SL, Bonda DJ, Lerner A, Tabaton M, Perry G, Smith MA: Dissociated amyloid-beta antibody levels as a serum biomarker for the progression of Alzheimer's disease: a populationbased study. Exp Gerontol 2010, 45:47-52.

18. Du Y, Dodel R, Hampel H, Buerger K, Lin S, Eastwood B, Bales K, Gao F, Moeller HJ, Oertel W, Farlow M, Paul S: Reduced levels of amyloid betapeptide antibody in Alzheimer disease. Neurology 2001, 57:801-805.

19. Dodel R, Neff F, Noelker C, Pul R, Du Y, Bacher M, Oertel W: Intravenous immunoglobulins as a treatment for Alzheimer's disease: rationale and current evidence. Drugs 2010, 70:513-528.

20. Klaver AC, Finke JM, Digambaranath J, Balasubramaniam M, Loeffler DA: Antibody concentrations to Abeta1-42 monomer and soluble oligomers in untreated and antibody-antigen-dissociated intravenous immunoglobulin preparations. Int Immunopharmacol 2010, 10:115-119.

21. Klaver AC, Patrias LM, Coffey MP, Finke JM, Loeffler DA: Measurement of anti- $A \beta 1-42$ antibodies in intravenous immunoglobulin with indirect ELISA: the problem of nonspecific binding. J Neurosci Methods 2010, 187:263-269.

22. Dodel RC, Du Y, Depboylu C, Hampel H, Frölich L, Haag A, Hemmeter U, Paulsen S, Teipel SJ, Brettschneider S, Spottke A, Nölker C, Möller HJ, Wei X, Farlow M, Sommer N, Oertel WH: Intravenous immunoglobulins containing antibodies against beta-amyloid for the treatment of Alzheimer's disease. J Neurol Neurosurg Psychiatry 2004, 75:1472-1474.

23. Relkin NR, Szabo P, Adamiak B, Burgut T, Monthe C, Lent RW, Younkin S, Younkin L, Schiff R, Weksler ME: 18-Month study of intravenous immunoglobulin for treatment of mild Alzheimer disease. Neurobio Aging 2009, 30:1728-1736.

24. Szabo P, Mujalli DM, Rotondi ML, Sharma R, Weber A, Schwarz HP, Weksler ME, Relkin N: Measurement of anti-beta amyloid antibodies in human blood. J Neuroimmunol 2010, 227:167-174.

25. Li Q, Gordon M, Cao C, Ugen KE, Morgan D: Improvement of a low pH antigen- antibody dissociation procedure for ELISA measurement of circulating anti-Abeta antibodies. BMC Neurosci 2007, 8:22

26. Klatka LA, Schiffer RB, Powers JM, Kazee AM: Incorrect diagnosis of Alzheimer's disease. A clinicopathologic study. Arch Neurol 1996, 53:35-42.

27. Jellinger KA: Criteria for the neuropathological diagnosis of dementing disorders: routes out of the swamp? Acta Neuropathol 2009, 117:101-110

28. Walsh DM, Selkoe DJ: Oligomers on the brain: the emerging role of soluble protein aggregates in neurodegeneration. Protein Pept Lett 2004, 11:213-228.

29. Bennett DA, Schneider JA, Buchman AS, Mendes de Leon C, Bienias JL, Wilson RS: The Rush Memory and Aging Project: study design and baseline characteristics of the study cohort. Neuroepidemiology 2005, 25:163-175.

30. Klaver AC, Patrias LM, Finke JM, Loeffler DA: Specificity and sensitivity of the Abeta oligomer ELISA. J Neurosci Methods 2011, 195:249-254.

31. Patrias LM, Klaver AC, Coffey MP, Finke JM, Digambaranath JL, Dang L, Martinez AA, Loeffler DA: Effects of external beam radiation on in vitro formation of Abeta1-42 fibrils and preformed fibrils. Radiat Res 2011, 175:375-381.

32. Du Y, Wei X, Dodel R, Sommer N, Hampel H, Gao F, Ma Z, Zhao L, Oertel WH, Farlow M: Human anti-beta-amyloid antibodies block betaamyloid fibril formation and prevent beta-amyloid-induced neurotoxicity. Brain 2003, 126:1935-1939.

33. Dodel R, Balakrishnan K, Keyvani K, Deuster O, Neff F, Andrei-Selmer LC, Röskam S, Stüer C, Al-Abed Y, Noelker C, Balzer-Geldsetzer M, Oertel W, Du Y, Bacher M: Naturally occurring autoantibodies against \{beta\}amyloid: investigating their role in transgenic animal and in vitro models of Alzheimer's disease. J Neurosci 2011, 31:5847-5854.

34. Istrin $\mathrm{G}$, Bosis $E$, Solomon $B$ : Intravenous immunoglobulin enhances the clearance of fibrillar amyloid-beta peptide. J Neurosci Res 2006, 84:434-443.

35. Legleiter J, Czilli DL, Gitter B, DeMattos RB, Holtzman DM, Kowalewski T: Effect of different anti-Abeta antibodies on Abeta fibrillogenesis as assessed by atomic force microscopy. J Mol Biol 2004, 335:997-1006.

36. O'Nuallain B, Acero L, Williams AD, Koeppen HP, Weber A, Schwarz HP, Wall JS, Weiss DT, Solomon A: Human plasma contains cross-reactive Abeta conformer- specific lgG antibodies. Biochemistry 2008, 47:12254-12256 
37. Balakrishnan K, Andrei-Selmer LC, Selmer T, Bacher M, Dodel R: Comparison of intravenous immunoglobulins for naturally occurring autoantibodies against amyloid-beta. J Alzheimers Dis 2010, 20:135-143.

38. Bitan G, Lomakin A, Teplow DB: Amyloid beta-protein oligomerization: prenucleation interactions revealed by photo-induced cross-linking of unmodified proteins. J Biol Chem 2001, 276:35176-35184.

39. Storace D, Cammarata S, Borghi R, Sanguineti R, Giliberto L, Piccini A, Pollero V, Novello C, Caltagirone C, Smith MA, Bossù P, Perry G, Odetti P, Tabaton M: Elevation of \{beta\}-amyloid 1-42 autoantibodies in the blood of amnestic patients with mild cognitive impairment. Arch Neurol 2010, 67:867-872.

40. Xia W, Yang T, Shankar G, Smith IM, Shen Y, Walsh DM, Selkoe DJ: A specific enzyme-linked immunosorbent assay for measuring betaamyloid protein oligomers in human plasma and brain tissue of patients with Alzheimer disease. Arch Neurol 2009, 66:190-199.

41. Sehlin D, Söllvander S, Paulie S, Brundin R, Ingelsson M, Lannfelt L, Pettersson FE, Englund $\mathrm{H}$ : Interference from heterophilic antibodies in amyloid-beta oligomer ELISAs. J Alzheimers Dis 2010, 21:1295-1301.

doi:10.1186/1742-2094-8-93

Cite this article as: Klaver et al.: ELISA measurement of specific nonantigen-bound antibodies to $A \beta 1-42$ monomer and soluble oligomers in sera from Alzheimer's disease, mild cognitively impaired, and noncognitively impaired subjects. Journal of Neuroinflammation 2011 8:93.

\section{Submit your next manuscript to BioMed Central} and take full advantage of:

- Convenient online submission

- Thorough peer review

- No space constraints or color figure charges

- Immediate publication on acceptance

- Inclusion in PubMed, CAS, Scopus and Google Scholar

- Research which is freely available for redistribution

Submit your manuscript at www.biomedcentral.com/submit 